\title{
Komentarz. Walsartan i jego preparaty - emocjonująca historia z pozytywnym zakończeniem
}

\author{
The commentary. Valsartan and its preparations: an exciting story \\ with a positive ending
}

prof. dr hab. n. med. Krzysztof J. Filipiak

I Katedra i Klinika Kardiologii Warszawskiego Uniwersytetu Medycznego

Praca Pań dr Agaty Tymińskiej i doc. Agnieszki Kapłon-Cieślickiej to solidne opracowanie poglądowe uprzytomniające nam, jak dobrze przebadaną substancją jest walsartan i jak ważne - także w kontekście aktualnych wytycznych dotyczących leczenia nadciśnienia tętniczego — są jego połączenia. Mamy ich trzy: $\mathrm{z}$ amlodipiną, $\mathrm{z}$ hydrochlorotiazydem, $\mathrm{z}$ rosuwastatyną. Od czasu, kiedy u większości chorych (wg zaleceń europejskich z 2018 r.) czy też praktycznie u wszystkich poniżej 65. roku życia (wg zaleceń polskich z 2019 r.) pierwszym lekiem po rozpoznaniu nadciśnienia tętniczego ma być połączenie leku hamującego układ renina-angiotensyna z diuretykiem lub antagonistą wapnia, dwa spośród tych połączeń (walsartan z amlodipiną oraz walsartan $\mathrm{z}$ hydrochlorotiazydem) zyskały sobie status leku pierwszego rzutu. Podkreślmy - pierwszego rzutu w terapii nadciśnienia tętniczego, niezależnie od tego, czy za takim statusem nadążają stare charakterystyki produktu leczniczego, czy jeszcze nie. Walsartan z rosuwastatyną także może być lekiem pierwszego rzutu, zwłaszcza u części chorych po 65. roku życia, którzy mogą rozpoczynać terapię nadciśnienia od jednego leku (monoterapia), ale w połączeniu ze statyną, gdy stwierdza się wspólistniejącą hipercholesterolemię.

Historia walsartanu poniekąd zatoczyła koło. Od początku wejścia na rynki farmaceutyczne sartany "starly się" z inhibitorami konwertazy angiotensyny (inhibitorami ACE [angiotensin-converting enzy$m e$ ]). Starcie to było nieuniknione, ponieważ de facto wprowadzono grupę leków działającą na ten sam układ fizjologiczny, nieco tylko różnicą się punktem uchwytu.

Rozpoczęła się - trwająca do dzisiaj — rywalizacja tych dwóch grup leków. Na początku wieku, w jego pierwszej dekadzie, wiele danych wskazywało na wyższość sartanów nad inhibitorami ACE w perspektywie patofizjologicznej (potencjalne działanie poprzez przekierowanie angiotensyny II na receptory $\mathrm{AT}_{2}$, lepszy wpływ tych leków na zdolności kognitywne od wpływu inhibitorów ACE, zmniejszanie bólów głowy, doskonały profil antymigrenowy). Wskazywano również na obszary terapeutyczne potencjalnej wyższości sartanów nad inhibitorami 
ACE (prewencja cukrzycy, regresja przerostu lewej komory, wspólistnienie chorób dróg oddechowych w związku z brakiem drażniącego wpływu lokalnie zwiększonych stężeń bradykininy, prewencja udaru mózgu). Większą rolę sartanom niż inhibitorom ACE $\mathrm{w}$ prewencji cukrzycy przypisywano na podstawie metaanaliz (Mancia i wsp., 2006; Elliot i wsp., 2006), przy udziale właśnie tych leków odnotowywano największe procentowe ograniczenie przerostu masy lewej komory w terapii hipotensyjnej (Klingbeil i wsp., 2003), a na podstawie badań head-to-head (bezpośrednie, prospektywne porównanie sartanów z inhibitorami ACE), takich jak ONTARGET, wskazywano na potencjalną, graniczną statystycznie wyższość sartanów nad inhibitorami ACE w prewencji udarów mózgu. W innych pracach wskazywano z kolei na wyższość inhibitorów ACE nad sartanami w chorobie wieńcowej, w prewencji zawału serca, w niewydolności serca. Nie do podważenia pozostała doskonała tolerancja leczenia związana z tą grupą leków. Nawet w najnowszych metaanalizach (Messerli i wsp., 2018) wskazuje się zresztą również na wyższość sartanów nad inhibitorami ACE pod względem skłonności chorych do dyskontynuacji przyjmowania leków. Po 20 latach tych zmagań obie grupy leków zajęły dobrą pozycję terapeutyczną, obie też należą do podstawowych grup środków hipotensyjnych; to od nich mamy obecnie rozpoczynać leczenie tej jednostki chorobowej. W zmaganiach tych prace z zastosowaniem walsartanu były kamieniem milowym, a sama substancja była w pewnej chwili - obok amlodipiny — jednym z najczęściej stosowanych leków na świecie.

Na tle zmagań między sartanami a inhibitorami ACE historia badań z zastosowaniem walsartanu wygląda imponująco, obejmując między innymi 15 245, 14703 i 5010 pacjentów w wielkich randomizowanych badaniach, odpowiednio: VALUE (Valsartan Antihypertensive Long-term Use Evaluation), VALIANT (Valsartan in Acute Myocardial Infarction Trial), Val-HeFT (Valsartan Heart Failure Trial). W badaniu NAVIGATOR (Nateglinide and Valsartan in Impaired Glucose Tolerance Outcomes Research) walsartan wykazywał właściwości zapobiegania (opóźniania) rozwoju cukrzycy typu 2, co nie udało się ramiprilowi, nawet $\mathrm{w}$ dużej dawce
$15 \mathrm{mg} /$ dobę, w badaniu DREAM. W badaniu MARVAL (MicroAlbuminuria Reduction with VALsartan) walsartan okazał się świetnym lekiem hipotensyjnym dla pacjentów z cukrzycą typu 2 i mikroalbuminurią, z kolei w Val-MARC (Valsartan-Managing blood pressure Aggressively and evaluating Reductions in hsCRP) znamiennie statystycznie obniżal parametry zapalne, a w jeszcze innych pracach przejawiał również korzystny wpływ na aktywność seksualną leczonych nim mężczyzn z nadciśnieniem tętniczym. Dodajmy wreszcie, że to właśnie walsartan stał się „ikoną” chronofarmakologii nadciśnienia tętniczego - wielokrotnie wykazano, że podawany na noc ma szczególnie korzystne właściwości poprawy profilu dobowego ciśnienia tętniczego.

Historia połączenia walsartanu $\mathrm{z}$ amlodipiną również imponuje. Skojarzenie to, zarejestrowany w 2007 roku w Stanach Zjednoczonych i w 2008 roku w Polsce, ma za sobą dekadę doświadczeń, ale dopiero teraz rozpoczyna "drugie życie" jako potencjalny środek hipotensyjny "pierwszego rzutu” w nowo rozpoznanym nadciśnieniu tętniczym.

Gdzie więc te, zapowiedziane w tytule niniejszego komentarza, „emocje” związane z walsartanem? Mimo że są jeszcze świeże, to warto przypomniećich chronologię. Autorki przypominają w swoim artykule to, co wydarzyło się w 2018 roku. Wstrzymanie obrotu niektórymi produktami zawierającymi substancję czynną walsartanu pochodzącą z reguły od chińskich wytwórców z powodu wykrycia zanieczyszczenia potencjalnie rakotwórczą N-nitrozodimetyloaminą (NDMA, N-nitrosodimethylamine) dotyczyło praktycznie wszystkich producentów poza oryginalnym walsartanem produkowanym przez firmę Novartis ${ }^{\circledR}$ oraz walsartanami produkowanymi we własnej fabryce przez firmę Krka ${ }^{\circledR}$. To te dwa źródła pochodzenia walsartanu okazały się bezpieczne, godne zaufania, odporne na "kryzys walsartanowy" z 2018 roku.

Dlaczego sprawa stała się taka głośna? Otóż NDMA ma właściwości hepatotoksyczne; powiązano ją z wywoływaniem wielu rodzajów nowotworów, między innymi wątroby, jelita grubego, płuc, trzustki, żołądka, nerek, pęcherza moczowego, przełyku i języka. Wprawdzie ryzyko rakotwórcze jest, jak się wydaje, minimalne, ale przecież mówimy o terapii choroby nadciśnieniowej - stanu, w którym 
lek przyjmuje się przewlekle przez 20,30, a niekiedy i 40 lat. Dlatego trudno oszacować ryzyko w odległej perspektywie. Musimy w takim przypadku mieć pewność co do czystości preparatu i jego jakości.

O ile obecność NDMA dotyczyła w 2018 roku tylko niektórych produktów walsartanu, o tyle stwierdzenie pokrewnych, również potencjalnie rakotwórczych związków (N-nitrozodietyloamina [NDEA, $\mathrm{N}$-nitrosodiethylamine], kwas N-nitrozo-N-metyloamino masłowy [NMBA, N-nitroso-N-methylamino butyric acid]) na przełomie lat 2018 i 2019 dotyczyło też irbesartanu i losartanu. Historię wycofywania tych sartanów i ich połączeń z perspektywy amerykańskiej Agencji ds. Żywności i Leków (FDA, Food and Drug Administration), przedstawiono na rycinie 1.

Okazało się zatem, że nie jest to problem tylko jednej cząsteczki - walsartanu, ale potencjalnie także wielu produktów: losartanu, irbesartanu, a może także kandesartanu i olmesartanu. Przy czym niepożądane, rakotwórcze cząsteczki powstają tylko w przypadku wybranych szlaków syntezy (tańszych, uproszczonych, stosowanych z reguły przez producentów substancji aktywnej w Chińskiej Republice Ludowej). Utrzymanie własnej, opartej na sprawdzonych szlakach syntezy produkcji walsartanu - chociaż droższe - okazało się technologią bezpieczną i przyszłościową. I to właśnie zarówno takie walsartany, jak i ich połączenia (w tym połączenia walsartan-amlodipina) są dziś dostępne na polskim rynku, i takie właśnie połączenia rekomendujemy polskim lekarzom.

Emocjonująca historia walsartanu i jego połączeń — od "wzlotów” w postaci doskonałych wyników badań, poprzez "kryzys" tanich, uproszczonych syntez i zalewu generycznych, słabej jakości leków - przechodzi z powrotem $w$ fazę zaufania do spraw-

\section{NDMA}

\section{NDEA NMBA}

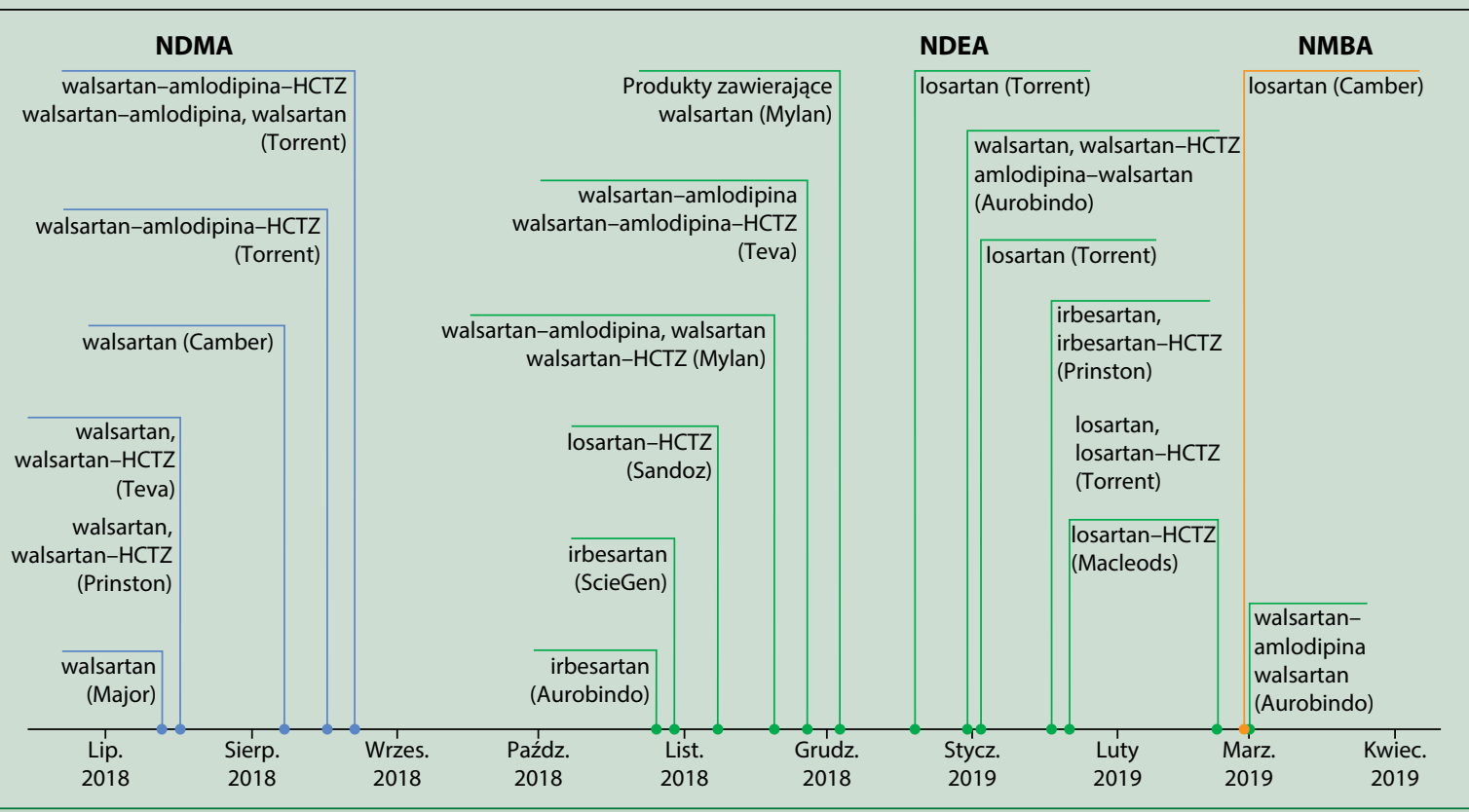

Rycina 1. Chronologiczny zapis „kryzysu walsartanowego”, który okazał się kryzysem kilku sartanów, a dokładniej kilku producentów. Zastosowali oni potencjalnie tańsze, mniej bezpieczne szlaki syntezy, które w przypadku niektórych sartanów o określonej budowie chemicznej (walsartan, losartan, irbesartan, kandesartan, olmesartan) mogą doprowadzić do obecności w produkcie finalnym potencjalnie niebezpiecznych związków - zanieczyszczeń (zmodyfikowano na podstawie publikacji z N. Engl. J. Med., dostęp publiczny, 29.04.2019). Nazwy producentów podane w nawiasach dotyczą podmiotów odpowiedzialnych za lek na rynku amerykańskim; NDMA ( $N$-nitrosodimethylamine) - N-nitrozodimetyloamina; HCTZ (hydrochlorothiazide) - hydrochlorotiazyd; NDEA (N-nitrosodiethylamine) - N-nitrozodietyloamina; NMBA ( $N$-nitroso- $N$-methylamino butyric acid) — kwas N-nitrozo-N-metyloamino masłowy 
dzonych, dobrych produktów tego przedstawiciela sartanów. Ta emocjonująca historia z pozytywnym zakończeniem nauczyła nas, lekarzy praktyków, kilku ważnych aspektów bezpieczeństwa terapii, których cały "kryzys walsartanowy” w Polsce był doskonałą egzemplifikacją. Podsumowałbym te doświadczenia, z perspektywy ponad roku, w czterech punktach:

1) poza znajomością medycyny opartej na dowodach naukowych (EBM, evidence-based medici$n e)$, farmakologii klinicznej danej grupy leków, danego leku w obrębie grupy i jego pozycji w wytycznych dotyczących leczenia nie można pomijać kwestii jakości preparatu danego leku. Kwestii tej trzeba będzie poświęcić dodatkowe kształcenie lekarzy, którzy obecnie mają bardzo ograniczoną wiedzę $w$ tym zakresie;

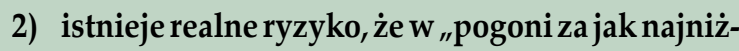
szą ceną" wielu producentów będzie szukać najtańszych substancji czynnych produkowanych w niebezpieczny sposób (często w Azji), konfekcjonowanych następnie w Europie i sprzedawanych jako "polskie leki"/,własne leki" - krytyczne podejście do marketingu takich preparatów również musi być uwzględnione w edukacji lekarzy;

3) stwierdzenie zanieczyszczenia w preparacie jednego producenta czy nawet kilku producentów dotyczących substancji $X$ nie może implikować nieuzasadnionych, nerwowych działań i namawiania lekarzy do całkowitej rezygnacji z substancji $X$ oraz zastępowania jej innymi lekami z tej samej grupy —z taką sytuacją mieliśmy, niestety, do czynienia w przypadku części ekspertów w Polsce, nieprzygotowanych do reagowania na taką sytuację;

4) właściwie produkowane, pozbawione zanieczyszczeń, mające długą tradycję stosowania walsartany i ich połączenia (walsartan-amlodipina/walsartan-hydrochlorotiazyd) niezmiennie pozostają ważnymi lekami hipotensyjnymi, a ich znaczenie w świetle nowych wytycznych istotnie się zwiększa.

\section{KONFLIKT INTERESÓW}

Honoraria za wykłady, granty wyjazdowe lub udział w badaniach klinicznych: Alfasigma, Bayer, Boehringer Ingelheim, Krka, Merck, MSD, Pfizer, Sandoz, Servier. 